\title{
Foreign Exchange Intervention in Emerging Markets: A Survey of Empirical Studies
}

\author{
Lukas Menkhoff \\ Discussion Paper No.498 \\ April 2012 \\ ISSN 0409-9962
}

\begin{abstract}
Nowadays foreign exchange interventions occur in emerging market economies whereas empirical studies on interventions mainly refer to advanced economies. However, interventions in emerging markets are different from those in advanced economies: they occur "regularly" and central banks have considerable leverage, derived from relatively high reserves, some non-sterilization, the central bank's information advantage and capital controls. Consequently, these interventions often successfully impact the level and volatility of exchange rates. Nevertheless, more research on interventions in emerging markets is needed analyzing the influence of heterogeneous institutional circumstances, examining the role of central bank communication and using high-frequency data.
\end{abstract}

JEL-Classification: F 31 (foreign exchange), E 58 (central banks and their policies), O 23 (monetary policy in development)

Keywords: $\quad$ foreign exchange, central bank intervention, emerging markets, transmission channels

For helpful comments and research assistance I would like to thank Fabian Baetje, Oliver Gloede, Marie Holzhausen, two anonymous referees and the associate editor, Zhihong Yu.

Leibniz Universität Hannover, Department of Economics, Königsworther Platz 1, D-30167 Hannover, Germany; menkhoff@gif.uni-hannover.de 


\section{Foreign Exchange Intervention in Emerging Markets:}

\section{A Survey of Empirical Studies}

\section{Introduction}

There is a broad literature on various aspects of foreign exchange interventions which is still focused on advanced economies, in particular regarding empirical intervention studies. By contrast, the world economy is changing towards a continuously increasing importance of emerging market economies. This move is particularly pronounced in foreign exchange as advanced economy countries are not the main owners of currency reserves anymore. Change is even more dramatic regarding foreign exchange interventions as the major central banks domiciled in the advanced economies - have almost stopped intervening during the last decade or so. This leads to the unpleasant situation that most of our empirical research and literature refers to institutional circumstances that do no longer fit the typical case in the present world: foreign exchange intervention is nowadays mainly an issue in emerging markets. This study discusses available knowledge and open questions with a focus on empirical research.

The existing discrepancy between intervention reality and empirical intervention literature may be illustrated by the following facts. Regarding the present real world situation, G7 central banks do not intervene with large amounts, if at all. In fact, it is basically the Bank of Japan left that practiced relevant interventions until 2004; a unique exception was the coordinated G7-interventions in March 2011 in order to support Japan. The situation is very different in emerging (and developing) countries. According to the IMF (2010, p.24), 65 percent of its members "publish some sort of intervention data", i.e. this share will be even higher when the non-intervening advanced economies are excluded and unpublished activity would be included. In an earlier survey among its non-advanced economy member countries, 91 percent of the 76 respondents state to conduct foreign exchange interventions (Canales-Kriljenko, 
2003, Table 2). So, emerging market economies have become more important than advanced economies in the area of foreign exchange intervention.

This fact is not fully reflected in academic research yet because foreign exchange intervention in emerging markets is nicely covered in some aspects, whereas it is under-researched in others. Good coverage refers to the choice of exchange rate regimes (e.g., Klein and Shambaugh, 2010). Also some issues with high relevance for emerging markets are broadly discussed, such as the accumulation of reserves (e.g., Aizenman and Lee, 2008) or the case of East Asia and China (e.g., McKinnon and Schnabl, 2009). However, when it comes to empirical studies on foreign exchange interventions, established surveys indicate a severe lack of consideration. For example, Sarno and Taylor (2001) do not cover a single study which would specifically address emerging markets and Neely's (2005) comprehensive survey about empirical work has a share of 2 out of 41 studies which are based on evidence from emerging markets.

However, already a first look at the present situation of emerging markets indicates that a closer examination would be worthwhile. These countries feel a need for exchange rate management, as they are heavily outwards oriented, are tentatively less diversified than more mature markets, have less developed financial institutions and are thus concerned about their exchange rate stability (see Calvo and Reinhart, 2002, Leijonhufvud, 2007, Schnabl and Hoffmann, 2008). The wish for exchange rate management and the willingness to use foreign exchange interventions is met by an institutional environment that seems to be conducive towards such interventions. These issues are laid out in more detail in the following and are supported by reference to empirical work. Nevertheless, evidence from empirical intervention studies is still scant, so there is much room and urgent need for more research.

The studies on emerging markets that are closest to ours are Canales-Kriljenko (2003), Hutchison (2003) and Disyatat and Galati (2007). These studies have a specific focus each. Canales-Kriljenko (2003) mainly reports results of an IMF survey among central banks about 
their view on interventions. Hutchison (2003) explores the role of interventions as an additional instrument of macroeconomic policy and has a focus on the Chiang Mai Initiative of 2000 towards better Asian cooperation on exchange rate management. Disyatat and Galati (2007) mainly present an empirical analysis of foreign exchange intervention in the Czech Republic. Consequently, there does not seem to be another general, comprehensive and recent account of foreign exchange intervention in emerging markets.

In the following, Section 2 presents an overview about exchange rate management in emerging markets, Sections 3 reports (stylized) facts about interventions in emerging markets and Section 4 highlights institutional characteristics of these markets in relation to advanced economies. These sections lay the foundation to better understand the environment of empirical studies on intervention impacts assessed in Section 5. Policy and research implications are discussed in Sections 6 and 7 respectively. Section 8 concludes.

\section{Exchange rate management in emerging markets}

The exchange rate is "perhaps the most important asset price" in the globalizing economy (Rose, 2011, 652). It may be thus not surprising that countries often follow practices of an active exchange rate management. We shortly review literature about this management in order to put our focused survey into a broader perspective.

Exchange rate management is motivated by economic reasons that countries have to manage their exchange rates instead of letting them freely float in foreign exchange markets. Quite generally, managed exchange rates tend to develop in a more stable way than freely floating exchange rates. The stability of the exchange rate directly influences, and potentially supports, the overall macroeconomy through at least three channels. First, the exchange rate impacts export volume and thus growth and employment. Second, the exchange rate impacts import prices and thus inflation. Third, exchange rate volatility impacts trade, risk premia and 
possibly growth (see Bacchetta and van Wincoop, 2000, McKinnon and Schnabl, 2004, Aghion et al., 2009).

Accompanying these potential advantages of exchange rate stabilization there are also risks. Most generally, the risk of market failure with flexible rates is substituted by policy failure with managed rates which can be substantial as, for example, episodes in the history of the Bretton Woods System or the Asian crisis 1997/98 have shown (Eichengreen, 2008). These risks include unwillingness of devaluation which often leads to a forced recession and later currency crisis, or the unwillingness of appreciation which may lead to currency wars, monetary overexpansion and excessive accumulation of reserves.

In the end it may be an empirical issue whether and to which degree stabilization of exchange rates is desirable. Unfortunately, the complexity following from very diverse institutional circumstances seems to be too large to derive simple rules of thumb for an optimal exchange rate management. The cross-country work by Klein and Shambaugh (2010), being complemented by Rose (2011), produces just three robust lessons: first, exchange stabilization fosters trade (although to a limited extent only), second, very small countries tend to peg their currencies, and third, "all large rich economies float" (Rose, 211, 664). That means, for most countries of interest there is no simple recipe what to do.

So countries have to make decisions on their exchange rate management and we observe that "corner solutions" to exchange rate regimes, i.e. either absolutely fixed or floating exchange rates, are much less popular in practice than intermediate solutions (Calvo and Reinhart, 2002, see also Fischer, 2001). A prominent case in this respect is China which clearly manages its exchange rate. Consequences of this policy are heavily disputed, in particular whether positive effects reach beyond China and its neighboring countries (McKinnon and Schnabl, 2009, 2012). We conclude that there is high demand for active exchange rate management, for example by relying on interventions. This "normality" of interventions for 
emerging markets is also reflected by discussing it as a regular policy instrument when responding to crises (e.g. Ghosh et al., 2009).

Reinhart and Rogoff (2004) have convincingly demonstrated that de facto exchange rate regimes often differ from stated regimes. We therefore follow their de facto classification of a "coarse grid" into five different exchange rate arrangements, i.e. pegs, regimes of limited flexibility (mostly crawls), managed floating, freely floating and freely falling exchange rates (the last "arrangement" indicates the failure of any functioning order). As we are interested in typical practices of emerging market economies we allocate them to these exchange rate regimes and for comparative purposes we employ the same allocation for other non-advanced and the advanced economies as well. The classification of economies follows the IMF's convention.

$\underline{\text { Table } 1}$ shows the resulting allocation of countries to exchange rate arrangements. It becomes obvious that emerging markets are heavily clustered in the intermediate regimes, i.e. they do not follow primarily pegs or floating regimes. These intermediate regimes require measures of exchange rate management. Calvo and Reinhart (2002) state in this respect that interest rate policy has become more popular over time but foreign exchange interventions still keep a prominent place.

Another motivation for examining intervention in emerging markets is provided by Neely's (2008) worldwide survey of central bank authorities' beliefs. Whereas respondents quite unanimously agree that a signaling channel of intervention works ("signaling future monetary or other official exchange rate policy") there is disagreement among the total group of central bankers on the portfolio balance channel ("altering relative supplies of domestic/foreign bonds in private portfolios”, quotes from Neely, 2008, Table 2). Interestingly, respondents from emerging markets are significantly more optimistic than respondents from advanced economies on the relevance of the portfolio balance channel. It seems to fit this view that the former regard a larger size of intervention as important for its success, whereas respondents from advanced economies do not share this view. 
Neely's results are largely supported by a survey of the Bank for International Settlements with 19 responding central banks from emerging markets. They indeed report that the portfolio balance channel is seen as (sometimes or most of the time) effective but they see an even stronger effectiveness of interventions on expectations (Mihaljek, 2005, Table 4).

So, authorities in emerging markets prefer exchange rate regimes which require exchange rate management. A popular instrument in this respect is intervention and authorities seem to believe that they cannot only impact expectations of market participants (signaling channel) but that they can impact the exchange rate directly by large intervention (portfolio balance channel). Some empirical substantiation why this could work is discussed next.

\section{Facts about foreign exchange intervention in emerging markets}

The conduct of foreign exchange intervention is in many senses identical to the one in advanced economies but in some important ways it is different. These differences help strengthening the impact from interventions.

Possibly, the most outstanding fact about intervention in non-advanced economies is its widespread use. As mentioned above, 91 percent of respondents to the IMF survey say that they use interventions. This picture qualitatively holds over all nine exchange rate regimes distinguished by this survey. The lowest share of interventionists is $67 \%$ for countries with an - obviously credible - currency board, otherwise it is always above 77\% (Canales-Kriljenko, 2003, Table 2).

The way by which interventions are conducted is in many respects similar to the "standard" procedures of advanced economy countries. Accordingly interventions are conducted in the spot market because it is most liquid and often leads price changes. The counterparty of central banks is mainly banks. Often government institutions are also involved. Finally, interventions occur through various trading platforms. As in advanced economies, the dominant trading way is via telephone orders but also online trading systems are prevalent and, surpris- 
ingly high, $18 \%$ of authorities in emerging markets also used electronic brokerage already in 2001 (Canales-Kriljenko, 2003, Table 3).

Two facts, however, differ markedly from interventions in advanced economies, i.e. large reserves and non-sterilization. Traditionally, reserves have been a privilege of higher income countries and thus advanced economies. Figure 1 shows, indeed, that advanced economies were dominating other countries in this respect until the late 1980s as they owned the vast majority of reserves. The figure shows moreover that this has become history. Nowadays non-advanced economy countries control most currency reserves and among them emerging market countries dominate.

This dominance is exemplified by highlighting those 20 countries with the largest currency reserves at the end of 2009. Figure 2 presents these countries in declining order of their reserves' size, led by China etc. In addition to the absolute amount of reserves, Figure 2 also gives two ratios for each country. The first row gives the ratio of reserves to GDP and the second row relates reserves to the volume of exports. These two ratios demonstrate even more impressively the change that has occurred in the world economy over the last decades: emerging markets do not only posses the largest volumes of currency reserves but the amount of these reserves in relation to the respective economies' size is even more important in economic terms than in advanced economies. This is a first dramatic remarkable between both country groups.

A second important difference, mentioned in short above, is the fact that advanced economy countries almost routinely sterilize the effect of intervention on the monetary base whereas non-advanced economy countries do not necessarily follow this practice. The IMF survey reveals that only $25 \%$ of non-advanced economies always sterilize foreign exchange intervention, whereas $12 \%$ do never and $64 \%$ do sometimes sterilize (Canales-Kriljenko, 2003, Tables 4 to 6). There is no doubt in the literature that non-sterilization strengthens the impact of intervention (Sarno and Taylor, 2001). 
Overall, foreign exchange interventions in emerging markets are conducted similarly to those in advanced economy countries with two remarkable differences: reserves are much higher and interventions are not routinely sterilized - both differences make the instrument potentially more powerful.

\section{Intervention environment of emerging markets}

Interventions in emerging market countries occur in an institutional environment that differs from advanced economy countries. This environment has ambivalent but overall rather supportive influence on the impact of interventions.

In order to visualize the situation of intervening central banks in emerging versus mature markets, Figure 3 provides a highly stylized overview about the size of participants in the respective foreign exchange market. The figure considers the central bank, commercial banks operating as intermediaries or speculators, funds (mutual funds, insurance firms etc.), corporate customers mainly covering hedging demands and foreign participants of all kinds (mainly from the financial industry). It becomes obvious that central banks in emerging economies are in a much better situation to control the market - just due to their sheer size. In the following we shortly justify the relative sizes sketched in the figure.

(1) The relative size of central banks in emerging versus advanced economies: We know from the development process of financial markets that central banks have a relatively larger size in developing and emerging economies compared to advanced economies (Levine, 1997). This relative size advantage is quite pronounced in foreign exchange, partially due to consciously taken policy measures.

(2) The size of banks: A widespread policy in emerging markets is the restriction of commercial banks' operations in the foreign exchange market. An example for such a policy is an active market making activity of the central bank by providing a narrow spread which can hardly be matched by private competitors. By contrast, banks in mature markets are typi- 
cally the largest group in the market when measured by transaction volume, although most of their activity is intermediation and less so speculation.

(3) The size of funds: Funds hardly exist in developing countries or if so, they are often state-controlled; in emerging markets they are of increasing importance but starting from a low base volume. In mature markets, however, professionally managed funds of various kinds (mutual, pension, hedge etc.) have become the most important force in foreign exchange markets as they nowadays at least match banks in transaction volume (Bank for International Settlements, 2010). Different from banks they are able to hold large open positions whereas most banks close positions at the end of each trading day (Gehrig and Menkhoff, 2005).

(4) The size of corporates: According to the Bank for International Settlements (2010), the volume of corporate customers in foreign exchange is much smaller than that of financial customers. Accordingly, the bar for corporates in Figure 3 is relatively smaller in the case of advanced economies but much larger in emerging market economies (see point (3) above). In order to easier compare advanced and emerging markets, however, we have set the size of corporate-bars the same at 100 for both country groups, so that it can be seen as a numeraire in Figure 3.

(5) Finally, foreigners play a central role in current foreign exchange trading. One can even say that national borders do not matter anymore among advanced economy countries and, consequently, the potential size of foreigners is overwhelming. This situation is obviously different for non-advanced economies as there are numerous kinds of capital controls in place. A far reaching measure in this respect is the fact that $30 \%$ of emerging and $70 \%$ of developing countries do not allow any offshore trading of the domestic currency (CanalesKriljenko, 2003, Table 19) - so, in these cases the foreign exchange market is clearly restricted and under close control.

Due to the small size of the interbank market, the relative size of interventions tends to be much larger in non-advanced economy countries as Figure 4 indicates. Here, the size of 
interventions in relation to indicators of the total foreign exchange market size is graphically presented for the 17 available non-advanced economy countries. For comparison purposes, the figure also includes respective numbers for the Bank of Japan as the most actively intervening major central bank. A related perspective is provided by Mihaljek (2005) who mentions that official reserves in emerging markets were 15 times the size of daily turnover of their currency whereas this ratio is just 0.5 in advanced economy countries.

In addition to the so far discussed quantitative aspects there is also a qualitative difference between emerging and mature markets: Central banks in emerging markets have a closer grip on the overall foreign exchange market because of their informational and regulatory power as Canales-Kriljenko (2003) shows. In particular, central banks (or authorities in general) are in more than $50 \%$ of reporting emerging countries the exclusive foreign exchange agent of the government (Table 8), in $36 \%$ of countries they impose surrender requirements to market participants (Table 9), in more than $90 \%$ of countries they impose net open foreign exchange position limits (Table 11), in about $50 \%$ of countries they prohibit residents from using foreign currency in various ways (Table 14), in more than $80 \%$ of countries they require the reporting of volume data (Table 18) and in $45 \%$ of countries both legs of foreign exchange transactions are settled at accounts at the central bank (Table 23). The information aspects are also discussed in the case study of Melvin et al. (2009). Mihaljek (2005, Table 5) provides self-reported evidence from emerging markets' central banks who mainly (14 out of 18) believe in an information advantage compared to others.

Overall, emerging markets' central banks are in a strong position when intervening as they have a relatively large size in the market, typically have an information advantage over private actors and can potentially make use of regulations to restrict unwanted behavior.

\section{Empirical findings on intervention impact in emerging markets}


In this section we review recent empirical examinations on the impact of foreign exchange interventions in emerging markets. Results indicate that intervention often has the desired impact. As these studies are quite diverse in their goals, methods and country coverage, we discuss them by country groups taking advantage of institutional similarities, starting with the Western Hemisphere, followed by Asia and Eastern Europe, whereas we are not aware of available studies about interventions in the few African emerging markets.

\section{A. Western Hemisphere}

One of the first empirical intervention studies in emerging markets is Tapia and Tokman (2004) reporting three intervention episodes of the Bank of Chile. It would be too far reaching for our purpose to present the detailed motivation for the central bank to intervene in various forms during these years. One can say, however, that Chile's economy went through turbulences, such as the Asian and the Argentinean crisis, which the central bank wanted to counteract. Tapia and Tokman (2004) use a time-series approach to find out whether interventions had an impact on the end-of-the-day exchange rate level, measured from day to day (see also Appendix Table). They find indeed that sales of US dollar in 1998/99 appreciated the Chilean peso. The elasticity is a $1 \%$ exchange rate change on 500 million US dollar intervention. However, intervention effects are not significant in the two later periods anymore. The authors explain this with a change in intervention policy as the central bank in the later period announced its intervention regime. If these announcements are taken into consideration, the exchange rate - rationally - reacts on announcements immediately so that announcements substitute the effect from actual interventions. Another - possibly complementary - explanation refers to the amount of interventions. In the 1998/99 period intervention size equaled nearly $10 \%$ of spot market transactions on intervention days (with a maximum of more than $30 \%$ ), whereas in 2001 it was less than 5\%. The intraday analysis available for the year 2001 suggests that the intervention impact on the exchange rate was rather short-lived, i.e. it often vanished within 10 to 20 minutes. 
Guimarães and Karacadag (2004) present an empirical account of Mexico's (and Turkey's) recent intervention experiences. They apply a modified GARCH approach to analyze intervention effects on exchange rate level and volatility with daily data. The long period for Mexico covers a regime where the central bank was buying US dollars in order to mainly build up currency reserves. As a second goal this policy should limit volatility and thus the bank was automatically buying whenever the Mexican peso was stronger than its 20-day moving average. In addition, the central bank 14 times sold US dollars in a discretionary manner to stabilize the exchange rate. The amount sold was about 200 mill. US dollar each time; this "represented a sizable fraction of daily turnover in the foreign exchange market" (Guimarães and Karacadag, 2004, p.10). The analysis shows that 100 mill. US dollar sales have a statistically significant two-day lagged impact on the peso of $0.4 \%$, whereas purchases have no effect. These sales also increase volatility in the short- and in the long-term, whereas purchases do not have a significant effect. However, other factors (which are controlled for) seem to be rather more important in explaining the Mexican peso's volatility.

For Colombia there are three studies, covering different periods, intervention objectives and instruments. Mandeng (2003) analyzes the use of currency options in 2002 to limit exchange rate volatility of the Colombian peso. So-called "volatility" options can be exercised at any time if the exchange rate is more than 4 percent away from its 20 -day moving average. For the few occasions where this instrument is used, the impact on volatility is small and rather short-lived, i.e. there is an effect within the next three days but not over a ten day period. The study also discusses which kinds of options should be used to maximize the impact. Interestingly, the option market was hardly used elsewhere (an exception is Mexico before 2002).

Accordingly, the later study by Kamil (2008) reports traditional intervention by the central bank of Colombia (but excludes a sub-period where options were used again). The method in this study is similar to Guimarães and Karacadag (2004) and examines the central 
bank's purchases of US dollar to stem an appreciation of its currency. Very interesting is the observation of two antagonistic sub-periods. From September 2004 to April 2006, the central bank followed an easing monetary policy, implying policy harmony with the foreign exchange interventions. From January to April 2007 it tightened its stance leading to a conflict between the two policy instruments. It is thus hardly surprising that intervention was somewhat successful in stabilizing the exchange rate in the beginning but largely failed later. All this happens despite relatively high intervention amounts which can be up to 50 percent of daily trading volume. This experience proves for an emerging market (controlling for several factors and endogeneity), that intervention has limited effectiveness as an independent policy tool and may even invite destabilizing speculation.

This line of argument is complemented by Rincón and Toro (2011) analyzing for Colombia the long period 1993 to 2010. They confirm earlier findings and extend them by considering the two policy tool of interventions and capital controls in combination. They show that a simultaneous use may support intervention effectiveness as intervention were able during the years 2008 to 2010 to effect the exchange rate trend without increasing volatility.

The last country studies from this world region are on Peru. Humala and Rodriguez (2010) cover a quite long period between 1993 and 2007 analyzing relations between foreign exchange interventions and exchange rate changes. This paper is intended to introduce into a research program and thus is a bit short in details. What is clearly interesting, however, is the application of a Markov switching process for modeling the relations of interest. There are indeed regime changes found in that interventions are larger in high volatility periods. During these periods, interventions seem to be more effective in moderating volatility.

Mundaca (2011) covers the shorter time period 2004 to 2009 also in Peru but uses intraday data. This study is different from most others in that the author analyzes intervention impact during the two hours of intervention time in comparison to the remaining hours. Intervention has desired effects during intervention time whereas it seems hardly able to shape expec- 
tations of market participants outside the narrow intervention window. This seems consistent with the interpretation that a portfolio balance channel is more powerful than a signaling channel; alternatively, the underlying assumptions about determinants of expectation formation may be mis-specified or other forces may overwhelm the impact of interventions, such as lacking credibility of authorities.

Finally, Adler and Tovar (2011) analyze interventions in a cross-country approach, mainly covering countries of the Western Hemisphere. They first assess the central bank reaction function and then the intervention effect on the exchange rate. Within the few episodes covered, interventions seem to be able to slow down appreciation, in particular if the capital account is less open and the currency is fundamentally misaligned. This indicates the importance of the policy environment for the success of interventions.

Summarizing experience from the Western Hemisphere, all studies examining level effects of interventions state some success of central banks, whereas the effects found on volatility are more mixed.

\section{B. Asia}

Pattanaik and Sahoo (2003) study the experience of India between 1995 and 2003. The exchange rate policy during this regime aims for keeping the real exchange rate constant and for ensuring orderly market conditions. The authorities use a full set of policy instruments to realize their ambitions, including monetary policy and capital controls. This makes it difficult to isolate an effect from interventions. It appears that interventions were mainly targeted to ensure orderly market conditions as the estimation of the intervention reaction function reveals that the central bank reacts on volatility in the foreign exchange market but not on misalignments. Giving this objective the interventions are found to be tentatively successful.

This conclusion is supported by two further studies on India. Behera et al. (2008) find a clear volatility reducing effect of interventions during the years 1995 to 2006; by contrast, foreign inflows tend to increase volatility. Goyal and Arora (2010) confirm the desired inter- 
vention impact on volatility for a more recent period, 2005 to 2008, with monthly and daily data. Both studies find either weak or no level effect, probably because the central bank does not target the exchange rate level.

The case of Turkey - analyzed by Guimarães and Karacadag (2004) - covers a sample period which starts directly after the country abandoned a crawling peg in February 2001 and began floating under difficult institutional and macroeconomic circumstances. Results show that interventions do not seem to impact the exchange rate level. One explanation may be that most interventions were preannounced so that the exchange rate may have reacted at the time of announcement - similar to the Chilean case. Other explanations might be instability over time (although a split into two sub-periods does not change the result qualitatively) or a possible impact of the non-considered discretionary interventions (which were found to be powerful in Chile). Regarding volatility, intervention has reduced volatility over the short-term but increased it over the long-term. However, any effect refers to sales of reserves only and these sales occurred during the first sub-period, i.e. until June 2002, “characterized by greater market and political uncertainty" (Guimarães and Karacadag, 2004, p.16). So, it seems a bit unclear, whether interventions were really the cause of persistent volatility.

A slightly shorter period for the Turkish lira is examined by Domaç and Mendoza (2004) in a somewhat different empirical framework. These authors find a short-term effect of intervention on the exchange rate level, a reduction of volatility which holds in the case of foreign currency sales only. So, findings are largely consistent with Guimarães and Karacadag (2004) and the interpretation is more favorable for the case of interventions.

Two longer intervention periods in the Turkish lira are examined by Herrera and Özbay (2005). The authors are mainly concerned with appropriately measuring dynamic intervention functions but also shortly report results about intervention impact. Their GARCH specification does not show an impact on the level of exchange rate (which fits to objectives) but a 
slight impact on increasing volatility in the free floating regime. However, the control for other determinants is very limited in this study.

The same period for Turkey as in Guimarães and Karacadag (2004) is again examined by Ardiç and Selçuk (2006) although by a somewhat different method. They apply a VAR system to study level and volatility effects. An interesting ingredient here is the EMBI spread (Emerging Markets Bond Index Plus) measuring the average investment risk in a larger set of emerging market bonds. The authors find that volatility of the Turkish lira decisively depends on shocks to the EMBI indicating the various determinants of exchange rate volatility and the importance of controlling for such factors. Moreover, they find that central bank interventions do reduce volatility, controlling for other determinants.

This finding for Turkey is largely supported by Akinci et al. (2006) for basically the same period. Different from most studies they apply an event study approach indicating only a weak impact of interventions on exchange rate volatility over the next 3 to 10 days, if at all. Moreover, they try to account for the above mentioned changing circumstances by a timevarying parameter approach in that they distinguish periods. Interventions impact the exchange rate level when large amounts of foreign currency are purchased.

Summarizing experience from Asian countries, studies do hardly find wanted level effects of interventions and only limited effectiveness in volatility reduction.

\section{Eastern Europe}

Intervention policy in the Czech Republic is analyzed by Égert and Komárek (2006) for the years 1997 to 2002. The authors start their investigation after turbulences in the foreign exchange market ended with a 10 percent depreciation of the Czech koruna in May 1997. From this time onwards the central bank followed a managed float with a 13 percent wide band. It also introduced an inflation targeting framework in early 1998. So, these environmental circumstances were stable over the period of examination. Moreover, the central bank predominantly aimed for exchange rate stabilization and thus mainly intervened against the ko- 
runa appreciation. The event study shows that authorities were quite successful in this respect for periods up to 60 days after intervention. A binding restriction is, however, that interest rate and intervention policies do work together: either interventions or interest changes alone are no significant determinants of exchange rate stability but a combination of both policy instruments is.

Disyatat and Galati (2007) examine a short sub-period of the Czech koruna with different methods. During the sample period in 2001-2002 the central bank bought about 3 bn. US dollar in order to lower the appreciation pressure on the Czech koruna. The authors first estimate the intervention probability in a reaction function equation and then, second, use these predicted intervention values in their impact assessment. They find that intervention never has an effect on volatility, neither contemporaneous nor lagged, that intervention has no contemporaneous effect on the exchange rate level, but that cumulated interventions impact the exchange rate level as well as a measure of expected changes ("risk reversal"). So, there is a statistically significant although economically limited shorter-term effect.

Gersl and Holub (2006) discuss intervention policy in the Czech Republic since 1998 although the empirical examination of interventions is just a section in their paper, covering the best documented period of 2001 and 2002. Their study has somewhat less favorable results for intervention policy than Disyatat and Galati (2007) as there is no level impact but a slight increase in volatility due to interventions. However, the methodological approach is simpler than in Disyatat and Galati (2007) as they do not consider endogeneity and control less for other determinants.

Another methodological variation is provided by Scalia (2008), who also analyzes interventions in the market for Czech koruna versus euro between July and December 2002. The author examines order flow, i.e. signed transactions which one can see as a measure of net buying pressure (Lyons, 2001). The market data on order flow come from the Reuters 3000 electronic trading system and cover an estimated 35\% share. Regarding intervention, Scalia 
(2008) provides reasonable arguments on the existence of interventions on a daily basis and their distribution during the day, which can be linked to the hourly order flow data. In addition, he distinguishes three intervention regimes with different degree of market knowledge about interventions. Better knowledge increases the impact of order flow, indicating that interventions provide information and support the signaling channel. The estimated price impact per 10 million euro order flow starts with 6.6 basis points for totally secret interventions increases to 9.3 basis points for partially expected interventions and almost doubles to 12.2 basis points for expected interventions. So, intervention seems to have a remarkable impact on the intraday exchange rate level and openness of interventions (versus secrecy) strengthens the impact.

Further experience from Eastern Europe is studied by Chmelarova and Schnabl (2006) for Croatia. During the period January 1996 to March 2005 the central bank intervened on 8 percent of all trading days and the authors examine determinants of these interventions, however, they do not analyze intervention impact. Interventions aim for exchange rate level and volatility stabilization. Interventions intend avoiding Croatian kuna depreciation, probably to shield the domestic banking system whose liabilities, denominated in foreign currency, would otherwise increase. Interestingly, capital controls may have reduced the need for intervention.

Égert and Lang (2006) examine interventions for Croatia during the same time as Chmelarova and Schnabl (2006). The success of interventions depends on circumstances and was higher during the second half of the sample period. Interventions were able to impact the exchange rate level to some extent whereas the effect of volatility changed according to conditions.

In a rare comparative study on six emerging economies Égert (2007) examines interventions in Croatia, the Czech Republic, Hungary, Romania and Slovakia ; we do not report findings on Turkey which is well covered by studies (see above). The comparative approach reveals cross-country differences as Croatia and Slovakia succeed in influencing their exchange 
rate level, Romania fails and the Czech Republic and Hungary are in between. The analysis of policy instruments shows that pure interventions are less successful than their combination with interest changes and oral interventions.

In another study, Melvin et al. (2009) analyze intervention in the market for Russian rouble versus US dollar. This study is methodologically different from the others as it covers a short sample (14 days in 2002) in a very comprehensive manner. In particular, data include total order flow in an electronic interbank market, including that of the Russian central bank. Moreover, the intervention approach is interesting as interventions are conducted by putting two very large limit orders into the existing electronic market which limit movements of the exchange rate. Due to voluminous foreign exchange reserves of the Russian authorities allowing for huge intervention orders in relation to market size and due to the overall high importance of the state in the Russian economy, the band seems to be credible and holds in the sample of investigation. However, a distinction of participants into informed versus less informed indicates that the informed rather trade against the band; as the upper border will be lifted later on, this experience proves the difficulty (and cost in form of reserve losses) to intervene against a trend (indicating fundamentals). Moreover, the relation between interventions and volatility is complex as volatility increases directly after interventions. However, volatility is lower during intervention days, indicating that the band seems to dampen volatility. Related to this tentative volatility decrease, intervention increases trading volume (liquidity) and reduces spread which both benefits the less informed participants in the market.

Summarizing experience from Eastern European countries, studies tentatively find level effects of interventions, but hardly effects towards volatility reduction. Overall, these studies indicate that foreign exchange intervention in emerging markets, in particular in the Western Hemisphere, can be surprisingly successful in the sense of influencing the level of the exchange rate. The results reported on volatility reduction are quite mixed and thus a bit disappointing from a policy perspective. However, there is a clear endogeneity problem as inter- 
ventions often occur in turbulent times, where identification is difficult and many studies do not control for this. Moreover, central banks follow different targets; India, for example, is successful in addressing volatility, whereas Eastern European countries tend to focus more on influencing their exchange rate level.

\section{Implications for intervention policy in emerging markets}

The empirical studies presented in Section 5 cautiously suggest some lessons for intervention policy in emerging markets which is different from advanced economies. One should be aware, however, that the few case studies available show a remarkable degree of countryspecific institutional characteristics and policy objectives.

First, central bank intervention often seems to have a significant impact on the exchange rate level. As a benchmark for assessing the impact, one may refer to the Evans and Lyons (2005) estimate of the impact that ordinary order flow has on the exchange rate which is estimated as 0.44 basis points per 10 million US dollar order flow in the most liquid Deutsche mark versus US dollar market in 1996. Compared to this benchmark, the respective figures for the Czech experience of between 7 to 12 basis points per 10 million euro seem remarkably high (Scalia, 2008). This gap in favor of intervention impact in emerging markets is underlined by available data from the other studies as reported in the Appendix Table. One should keep in mind although that these exact figures are in fact imprecise measures. Remarkably, the Evans and Lyons-benchmark figure underestimates the true impact in mature markets because Payne and Vitale (2003) have shown (for the Deutsche mark versus US dollar market) that the impact from interventions is significantly higher than from ordinary private order flow. Regarding the figures from emerging markets, studies cannot always control for the set of relevant competing exchange rate determinants.

Second, the main root for the central bank's market power is probably its large intervention volume in relation to the market's volume. Unfortunately, the studies surveyed in Section 
5 usually do not provide information about the amount of intervention relative to the total market but the available data indicate that the sheer size of interventions will often bring a portfolio channel to work.

Third, there are further channels operating that transmit the central banks' intentions to markets. As in advanced economies too, the central bank can use interest rate policy and oral communication policy as additional instruments to influence the foreign exchange market. Different from advanced economies, however, the central bank often has even more tools available due to its powerful position in the domestic financial sector. Most obvious is this power if instruments of capital control are applied.

Fourth, the effect from intervention on exchange rate volatility is less clear from the empirical studies, even though the central banks themselves strongly believe in their effectiveness in this respect (Mihaljek, 2005). Most studies find a damping effect of interventions on exchange rate volatility, some studies find the opposite. A somewhat reconciling result is suggested in Melvin et al. (2009) who differentiate the intervention impact according to horizon: the immediate impact is a volatility increase, indicating a flow of information into the market, but the subsequent impact is a volatility reduction, indicating a stabilization of market conditions. There is no question, however, that a stabilizing impact on volatility requires credibility of the intervention policy which hints at a more general issue.

Accordingly, fifth, any success of intervention policy depends on its credibility and this requires an appropriate setting of the overall economic policy (King, 2003). This is theoretically obvious, it is well-known from advanced economies (Sarno and Taylor, 2001) and there is also ample evidence provided by the empirical studies for emerging markets (see Section 5). Even though intervention policy may be more powerful in emerging markets than in advanced economies, it is not powerful enough to overrule basic fundamentals and economic strategies. 
On the positive side is that, sixth, the possible policy conflict between foreign exchange interventions and the monetary strategy of inflation targeting is not dramatic in the empirical studies referred to above. In theory, the conflict arises from the fact that interventions in emerging markets are often conducted without sterilization, thereby having an effect on monetary aggregates which may either support or contradict the concrete inflation targeting policy. In reality, however, it seems that most central banks in emerging markets aim for seriously controlling inflation anyway so that intervention policy has to be subordinated to the overarching goal of price stability. Égert (2007) reports successful intervention episodes although most central banks covered do sterilize their interventions.

Finally, the recent crisis has demonstrated that interventions can only be effective if central bank reserves are invested in save assets. The crisis stopped and even reversed the trend towards riskier investments of reserves, being motivated by higher expected returns (Pihlman and van der Hoorn, 2010).

\section{Implications for intervention research about emerging markets}

As thorough empirical research on foreign exchange interventions in emerging markets has just started some years ago, the comparison with research on advanced economies teaches that there are plenty of important issues to be addressed in the near future. We sketch a few that could be of particular interest, i.e. a systematic evaluation of institutional differences between emerging and advanced economies, the role of oral versus actual intervention and highfrequency analyses of interventions.

The most obvious fact regarding emerging markets is that they differ from the better researched advanced economies in their institutional development. This has two implications: first, it is warranted to better carve out in which way institutional differences between these two country groups influence the efficiency of interventions. Second, it should be informative to conduct comparative studies on intervention in a set of several emerging markets in order 
to identify more subtle critical institutional differences. Special attention should be given to structural changes in the institutional environment which is - according to the studies reviewed in Section 5 - less stable than in advanced economies.

Another field which has gained attention in research on advanced economies but which has been almost completely neglected in emerging markets so far (with the remarkable exception of Égert, 2007) is the communication of central banks. Although the main central banks of advanced economies hardly intervene anymore, they nevertheless heavily try to influence the foreign exchange market by their statement. This so-called oral intervention has been examined in several studies recently (see Fratzscher, 2008, and Beine et al., 2009, for further references). Studies find that oral intervention is effective for short and medium-term horizons. One may speculate whether central bank communication in emerging markets is refined enough to make use of this instrument, but some studies indicate that communication plays a role (e.g. Tapia and Tokman, 2004, Guimarães and Karacadag, 2004, on Turkey). This should motivate to carefully analyze this tool and assess possible policy implications.

Finally, the basic limitation in any research on foreign exchange interventions is the identification of an intervention impact. A strategy to minimize mistakes in identification is relying on high-frequency data which allow to precisely measure intervention and to differentiate its impact from other determinants of exchange rates. Studies for advanced economies have gained remarkable insights (Menkhoff, 2010). The bottleneck is data availability, such as precise intervention information (Fischer, 2006) and good high-frequency data on prices and other market statistics. Recognizing this bottleneck one should also accept the difficulty in examining volatility effects without high-frequency data; indeed, results of the available lower frequency studies are often inconclusive, see the cases of Turkey and Czech Republic discussed above. So, it would be most interesting to extend the high-frequency examination to emerging markets beyond the papers by Scalia (2008) and Melvin et al. (2009). 


\section{Conclusion}

Foreign exchange interventions may be more important as an instrument than often thought. Despite some relevance in advanced economies (Fratzscher, 2009) - when we talk about foreign exchange interventions today we should talk about emerging markets. This is the place where actual interventions heavily occur in these days. In contrast to this fact, empirical research about interventions in emerging markets has just started a few years ago and is still in a nascent stage. Available studies provide some first tentative lessons for policy and many suggestions for future research.

Interventions in emerging economies differ from advanced economies in several respects: first, they are rather the "regular" stance than non-intervention, reflecting a strong demand of these countries to manage their exchange rate. Second, the institutional setting gives intervening central banks clearly more leverage than in advanced economies. This "power" is derived from relatively higher reserves, a high degree of non-sterilization, the central bank's large information advantage and its command over further regulatory tools including capital controls. Third, it follows from this institutional environment, that interventions in emerging markets are often successful in impacting the level and volatility of exchange rates. Due to the sheer relative size of interventions, the portfolio balance channel may apply in addition to variants of the signaling (or: expectation) channel. However, the conventional caveat applies here too: interventions must be credible and should not occur contrary to fundamentals and the general policy stance.

Overall, institutional circumstances and policies followed are very diverse within the group of emerging markets motivating new research to find out commonalities and institution-specific insights. Further neglected research areas are the role of central bank communication in impacting the foreign exchange market and the methodological approach of highfrequency based analyses which helps to ensure intervention identification against competing exchange rate influences. These areas for further research on foreign exchange interventions 
in emerging markets are directly related to standard studies about interventions in advanced economies and will thus stimulate the whole field.

We conclude that the policy instrument of interventions is less subject to a "fall" in interest but to a shift to a new and in many ways under-researched area, i.e. emerging markets. 


\section{References}

Adler, Gustavo and Camilo E. Tovar (2011), Foreign exchange intervention: A shield against appreciation winds? IMF Working Paper WP/11/165.

Aghion, Philippe, Philippe Bacchetta, Roman Rancière and Kenneth Rogoff (2009), Exchange rate volatility and productivity growth: The role of financial development, Journal of Monetary Economics, 56, 494-513.

Aizenman, Joshua and Jaewoo Lee (2008), Financial versus monetary mercantilism: Long-run view of large international reserves hoarding, The World Economy, 31, 593-611.

Akinci, Özge, Olcay Yücel Culha, Ümit Özlale and Gülbin Sahinbeyoglu (2006), The effectiveness of foreign exchange interventions under a floating exchange rate regime for the Turkish economy: A post-crisis period analysis, Applied Economics, 38, $1371-1388$.

Ardiç, Oya Pinar and Faruk Selçuk (2006), The dynamics of a newly floating exchange rate: The Turkish case, Applied Economics, 38, 931-941.

Bacchetta, Philippe and Eric van Wincoop (2000), Does exchange-rate stability increase welfare and trade? American Economic Review, 90, 1093-1109.

Bank for International Settlements (2010), Triennial central bank survey - Report on global foreign exchange market activity in 2010, Basel.

Behera, Harendra, Vathsala Narasimhan and K.N. Murty (2008), Relationship between exchange rate volatility and central bank intervention: An empirical analysis for India, South Asia Economic Journal, 9, 69-84.

Beine, Michel, Gust Janssen and Christelle Lecourt (2009), Should central bankers talk to the foreign exchange market?, Journal of International Money and Finance, 28, 776803. 
Calvo, Guillermo A. and Carmen Reinhart (2002), Fear of floating, Quarterly Journal of Economics, 117, 379-408.

Canales-Kriljenko, Jorge Iván (2003), Foreign exchange intervention in developing and transition economies: Results of a survey, IMF Working Paper 03/95.

Chmelarova, Viera and Gunther Schnabl (2006), Exchange rate stabilization in developed and underdeveloped capital markets, ECB Working Paper No.636.

Disyatat, Piti and Gabriele Galati (2007), The effectiveness of foreign exchange intervention in emerging market countries: Evidence from the Czech koruna, Journal of International Money and Finance, 26, 383-402.

Domaç, Ilker and Alfonso Mendoza (2004), Is there room for foreign exchange interventions under an inflation targeting framework?, World Bank Policy Research Working Paper 3288.

Égert, Balázs (2007), Central bank interventions, communication and interest rate policy in emerging European economies, Journal of Comparative Economics, 35, 387-413.

Égert, Balázs and Lubos Komárek (2006), Foreign exchange interventions and interest rate policy in the Czech Republic: Hand in glove?, Economic Systems, 30, 121-140.

Égert, Balázs and Maroje lang (2006), Foreign exchange interventions in a small emerging market: The case of Croatia, Economic Change and Restructuring, 39, 35-62.

Eichengreen, Barry (2008), Globalizing capital: A history of the international monetary system, Princeton: Princeton University Press, $2^{\text {nd }}$ ed.

Evans, Martin D.D. and Richard K. Lyons (2005), Are different-currency assets imperfect substitutes?, in: De Grauwe (ed.), Exchange rate economics: where do we stand?, Cambridge: MIT Press, 1-38.

Fischer, Andreas M. (2006), On the inadequacy of newswire reports for empirical research on foreign exchange interventions, Journal of International Money and Finance, 25, 1226-1240. 
Fischer, Stanley (2001), Exchange rate regimes: Is the bipolar view correct? Journal of Economic Perspectives, 15, 3-24.

Fratzscher, Marcel (2008), Oral interventions versus actual interventions in FX markets - An event study approach, Economic Journal, 118, 1079-1106.

Fratzscher, Marcel (2009), How successful is the G7 in managing exchange rates?, Journal of International Economics, 79, 78-88.

Gehrig, Thomas and Lukas Menkhoff (2005), The rise of fund managers in foreign exchange: Will fundamentals ultimately dominate?, The World Economy, 28, 519-540.

Gersl, Adam and Tomás Holub (2006), Foreign exchange interventions under inflation targeting: The Czech experience, Contemporary Economic Policy, 24, 475-491.

Ghosh, Atish R., Marcos Chamon, Christopher Crowe, Jun I. Kim and Jonathan D. Ostry (2009), Coping with the crisis: Policy options for emerging market countries, IMF Staff Position Note SPN/09/08.

Goyal, Ashima and Sanchit Arora (2010), The Indian exchange rate and central bank action: A GARCH analysis, Working Paper, Indira Gandhi Institute of Development Research.

Guimarães, Roberto F. and Cem Karacadag (2004), The empirics of foreign exchange intervention in emerging market countries: The cases of Mexico and Turkey, IMF Working Paper 04/123.

Herrera, Ana Maria and Pinar Ozbay (2005), A dynamic model of central bank intervention: Evidence from Turkey, Central Bank of the Republic of Turkey Research Department Working Paper 05/01.

Humala, Alberto and Gabriel Rodriguez (2010), Foreign exchange intervention and exchange rate volatility in Peru, Applied Economics Letters, 17, 1485-1491.

Hutchison, Michael W. (2003), Intervention and exchange rate stabilization policy in developing countries, International Finance, 6, 109-127. 
IMF [International Monetary Fund](2010), Annual report on exchange arrangements and exchange restrictions, Washington, D.C.

Kamil, Herman (2008), Is central bank intervention effective under inflation targeting regimes? The case of Colombia, IMF Working Paper 08/88.

King, Michael R. (2003), Effective foreign exchange intervention: Matching strategies with objectives, International Finance, 6, 249-271.

Klein, Michael W. and Jay C. Shambaugh (2010), Exchange rate regimes in the modern era, Cambridge, MA: MIT Press.

Leijonhufvud, Christina (2007), Financial globalization and emerging markets volatility, The World Economy, 30, 1817-1842.

Levine, Ross (1997), Financial development and economic growth: Views and agenda, Journal of Economic Literature, 35, 688-726.

Lyons, Richard K. (2001), The microstructure approach to exchange rates, Cambridge et al.: MIT Press.

Mandeng, Ousmène (2003), Central bank foreign exchange market intervention and option contract specification: The case of Colombia, IMF Working Paper 03/135.

McKinnon, Ronald and Gunther Schnabl (2004), The East Asian Dollar standard, fear of floating, and original sin, Review of Development Economics, 8, 331-360.

McKinnon, Ronald and Gunther Schnabl (2009), The case for stabilizing China's exchange rate: Setting the stage for fiscal expansion, China \& World Economy, 17, 1-32.

McKinnon, Ronald and Gunther Schnabl (2012), China and its dollar exchange rate: A worldwide stabilizing influence? The World Economy, 35, forthcoming.

Melvin, Michael, Lukas Menkhoff and Maik Schmeling (2009), Exchange rate management in emerging markets: Intervention via an electronic limit order book, Journal of International Economics, 79, 54-63. 
Menkhoff, Lukas (2010), High-frequency analysis of foreign exchange interventions: What do we learn? Journal of Economic Surveys, 24, 85-112.

Mihaljek, Dubravko (2005), Survey of central banks' views on effects of intervention, BIS Papers No.24, 82-96.

Mundaca, B. Gabriela (2011), How does public information on central bank intervention strategies affect exchange rate volatility? The case of Peru, World Bank Policy Research Working Paper 5579.

Neely, Christoper J. (2005), An analysis of recent studies of the effect of foreign exchange intervention, Federal Reserve Bank of St. Louis Review, 87, 685-717.

Neely, Christopher J. (2008), Central bank authorities' beliefs about foreign exchange intervention, Journal of International Money and Finance, 27, 1-25.

Pattanaik, Sitikantha and Satyananda Sahoo (2003), The effectiveness of intervention in India: An empirical assessment, Reserve Bank of India Occasional Paper 22.

Payne, Richard and Paolo Vitale (2003), A transaction level study of the effects of central bank intervention of exchange rates, Journal of International Economics, 61, 331352.

Pihlman, Jukka and Han van der Hoorn (2010), Procyclicality in central bank reserve management: Evidence from the crisis, IMF Working Paper WP/10/150.

Reinhart, Carmen M. and Kenneth S. Rogoff (2004), The modern history of exchange rate arrangements: A reinterpretation, Quarterly Journal of Economics, 119, 1-48.

Rincón, Hernán and Jorge Toro (2011), Are capital controls and central bank intervention effective? Borradores de ECONOMÍA Núm.625, Banco de la República, Colombia.

Rose, Andrew K. (2011), Exchange rate regimes in the modern era: Fixed, floating, and flaky, Journal of Economic Literature, 49, 652-672. 
Sarno, Lucio and Mark P. Taylor (2001), Official intervention in the foreign exchange markets: Is it effective and, if so, how does it work? Journal of Economic Literature, 34, 839-868.

Scalia, Antonio (2008), Is foreign exchange intervention effective? Some micro-analytical evidence from the Czech Republic, Journal of International Money and Finance, $27,529-546$.

Schnabl, Gunther and Andreas Hoffmann (2008), Monetary policy, vagabonding liquidity and bursting bubbles in new and emerging markets: An overinvestment view, The World Economy, 31, 1226-1252.

Tapia, Matias and Andrea Tokman (2004), Effects of foreign exchange intervention under public information: The Chilean case, Economia, 4:2, 215-256. 
TABLE 1. Exchange rate arrangements in emerging markets

\begin{tabular}{|c|c|c|c|c|c|c|}
\hline \multirow[t]{2}{*}{ Arrangements } & \multicolumn{2}{|c|}{$\begin{array}{c}\text { Emerging } \\
\text { Markets }\end{array}$} & \multicolumn{2}{|c|}{$\begin{array}{l}\text { Other Non- } \\
\text { Advanced }\end{array}$} & \multicolumn{2}{|c|}{$\begin{array}{l}\text { Advanced } \\
\text { Economies }\end{array}$} \\
\hline & $\begin{array}{l}\text { absolute } \\
\text { number }\end{array}$ & $\begin{array}{l}\text { relative } \\
\text { share }\end{array}$ & $\begin{array}{l}\text { absolute } \\
\text { number }\end{array}$ & $\begin{array}{l}\text { relative } \\
\text { share }\end{array}$ & $\begin{array}{l}\text { absolute } \\
\text { number }\end{array}$ & $\begin{array}{l}\text { relative } \\
\text { share }\end{array}$ \\
\hline $\begin{array}{l}\text { - No separate legal tender/ } \\
\text { currency board/ peg/ band }{ }^{1}\end{array}$ & 3 & 12.0 & 54 & 47.0 & 19 & 63.3 \\
\hline - Crawling peg/band ${ }^{2}$ & 10 & 40.0 & 44 & 38.3 & 0 & 0.0 \\
\hline $\begin{array}{l}\text { - Crawling band/moving band/ } \\
\text { managed floating }\end{array}$ & 9 & 36.0 & 14 & 12.2 & 8 & 26.7 \\
\hline - Freely floating & 2 & 8.0 & 2 & 1.7 & 3 & 10.0 \\
\hline - Freely falling & 0 & 0.0 & 0 & 0.0 & 0 & 0.0 \\
\hline $\begin{array}{l}\text { - Dual market in which parallel } \\
\text { market data is missing }\end{array}$ & 1 & 4.0 & 1 & 0.9 & 0 & 0.0 \\
\hline Total & 25 & 100 & 115 & $100 \%$ & 30 & $100 \%$ \\
\hline
\end{tabular}

Source: Our calculations based on Ilzetzki, Reinhart and Rogoff (2008), “Annual classification of exchange rate regime, 1946-2007", http://terpconnect.umd.edu/ creinhar/Courses.html

${ }^{1}$ This classification includes furthermore the categories: Pre announced peg or currency board arrangements, pre announced horizontal band that is narrower than or equal to $+/-2 \%$ and de facto peg.

2 This classification includes the categories: Pre announced crawling peg, pre announced crawling band that is narrower than or equal to $+/-2 \%$, de factor crawling peg and de facto crawling band that is narrower than or equal to $+/-2 \%$.

${ }^{3}$ This classification includes furthermore the categories: Pre announced crawling band that is wider than or equal to $+/-2 \%$, de facto crawling band that is narrower than or equal to $+/-5 \%$ and moving band that is narrower than or equal to $+/-2 \%$ (i.e., allows for both appreciation and depreciation over time). 
FIGURE 1. The share of non-advanced countries in world-wide total reserves

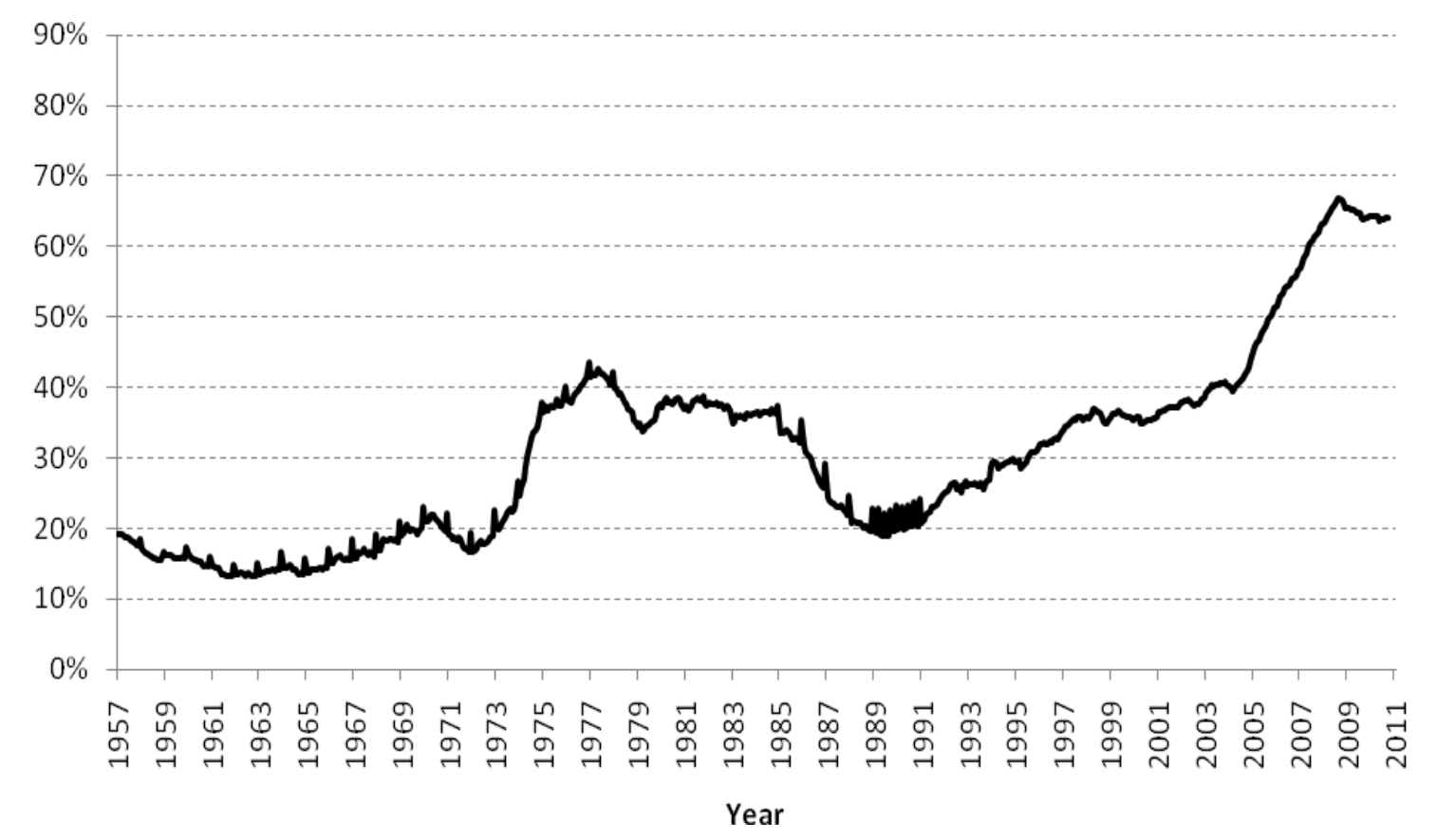

Source: Datastream; IMF International Financial Statistics, international reserves (TCI.1..SA, DCI.1..SA) 
FIGURE 2. The twenty largest owners of foreign exchange reserves at the end of 2009 (in billions of US dollar)

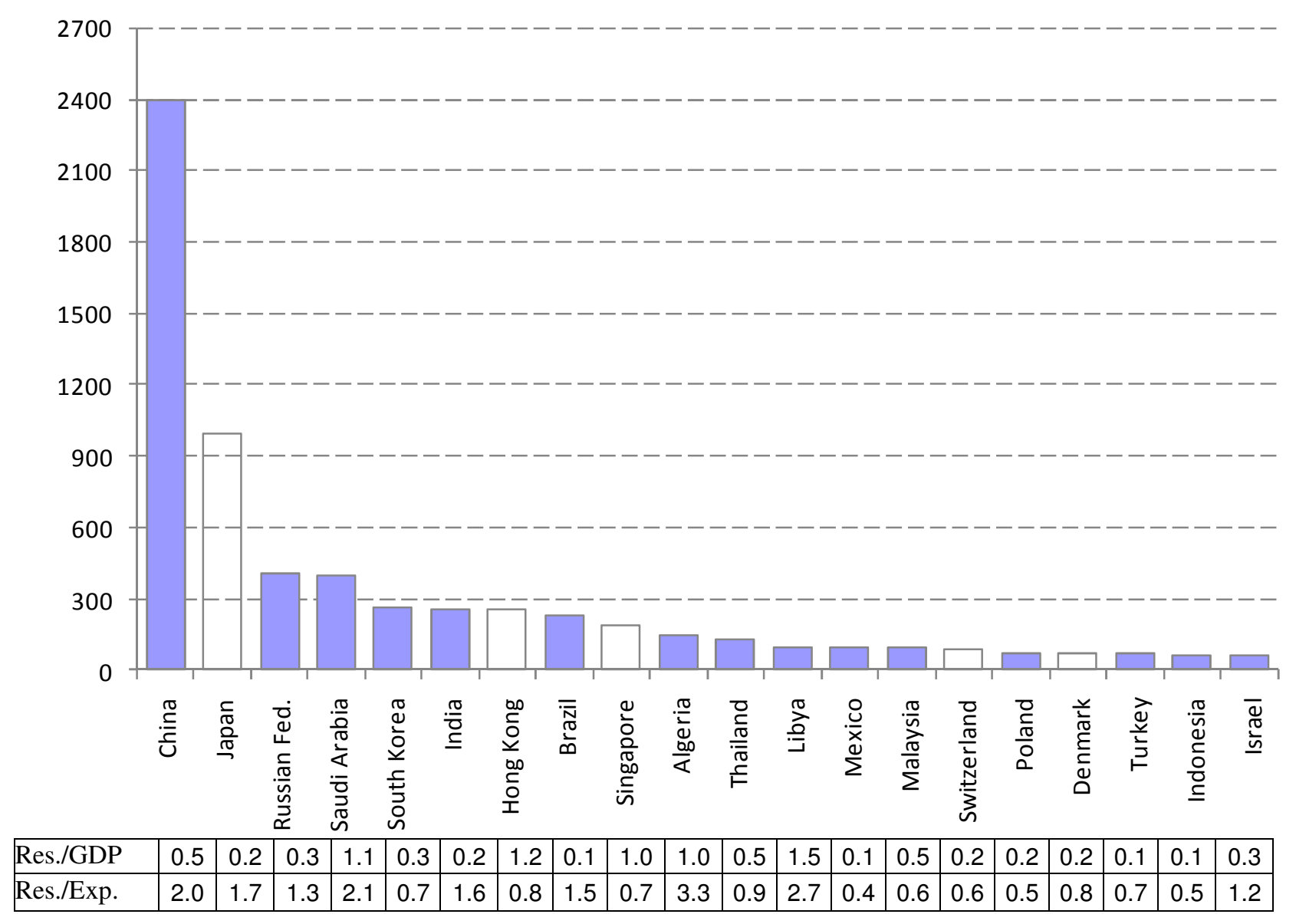

Note: Res./GDP represents ratio of reserves to GDP and Res./Exp. represents ratio of reserves to exports

Source: FX-Reserves and exports are taken from Datastream and IMF International Financial Statistics, the GDP's are extracted from the World Bank data set. 


\section{FIGURE 3. Illustration of the relative size of $\mathbf{F X}$ market participants}

in Emerging Markets

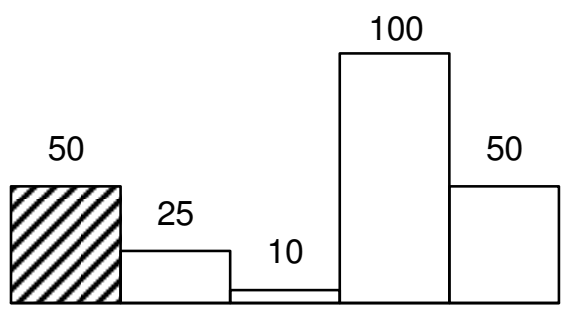

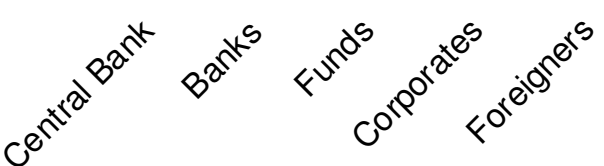

in Advanced Economies

150 150

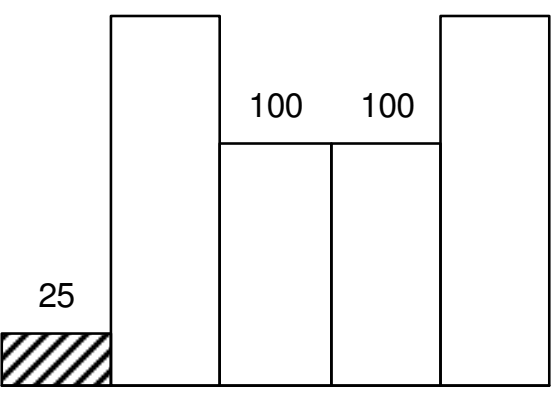



Note: The size of the bar illustrates (but does not exactly measure) the size of various market participants in the foreign exchange markets, in relation to the transaction of corporate customers which serve as numeraire (set to 100). The illustration is based on Bank for International Settlements (2010) and the bank's earlier reports.

FIGURE 4. The relative size of interventions to market transactions in non-advanced economies

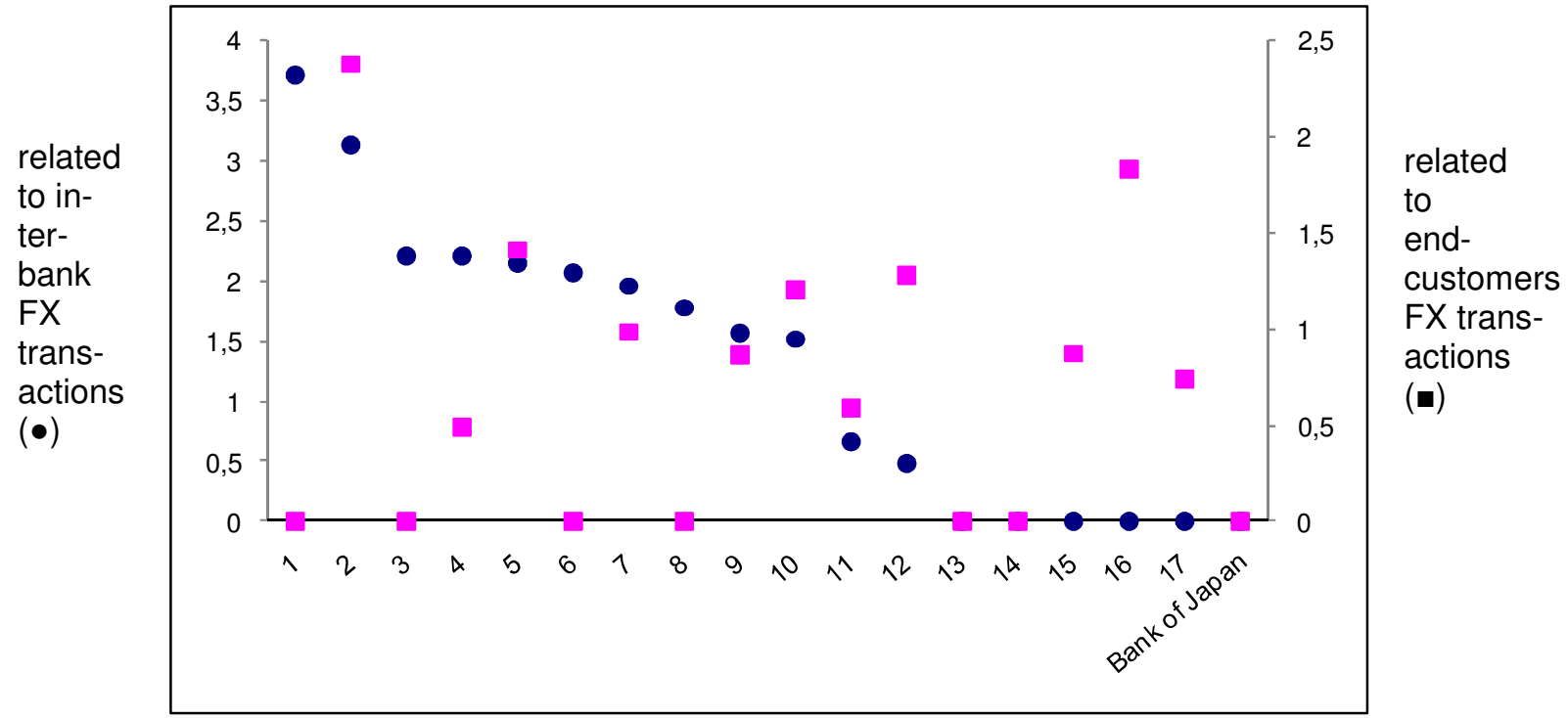

Source: Canales-Kriljenko (2003), Table 7

Note : The definitions in the IMF survey are "FX interventions in percent of interbank FX market turnover" (left scale, data transformed in log) and "FX interventions in percent of FX market turnover between bank and endcustomers" (right scale, data transformed in log). The database names 17 non-advanced countries for which data is available plus Japan. There are some missing values ( 3 for the first measure, 4 for the second). For every negative or missing value we assume that these values are zero. 
APPENDIX TABLE. Intervention (IV) studies about emerging markets

\begin{tabular}{|c|c|c|c|c|c|}
\hline$\overline{\text { Study }}$ & $\begin{array}{l}\text { Exchange } \\
\text { rates }\end{array}$ & $\begin{array}{l}\text { Period; fre- } \\
\text { quency }\end{array}$ & Method & Analyses and results & $\begin{array}{ll}\text { Im- }^{1} & \text { Im- }^{1} \\
\text { pact }^{1} & \text { pact }^{1} \\
\text { Lev. } & \text { Vol. }\end{array}$ \\
\hline
\end{tabular}

\begin{tabular}{|c|c|c|c|c|c|c|}
\hline \multicolumn{7}{|c|}{ WESTERN HEMISPHERE } \\
\hline $\begin{array}{l}\text { Tapia and } \\
\text { Tokman } \\
(2004)\end{array}$ & $\begin{array}{l}\text { Chilean } \\
\text { peso vs. } \\
\text { US dollar }\end{array}$ & $\begin{array}{l}1.98-9.99 \\
8.01-12.01 \\
10.02-2.03 \\
\text { daily; } 2001 \\
\text { also intraday }\end{array}$ & $\begin{array}{l}\text { time series, } \\
\text { OLS and } \\
2 \text { SLS }\end{array}$ & $\begin{array}{l}\text { - Control for macro and policy varia- } \\
\text { bles } \\
\text {-IV can have clear impact on exchange } \\
\text { rate level } \\
\text {-IV announcements are important }\end{array}$ & + & n.a. \\
\hline $\begin{array}{l}\text { Guimarães } \\
\text { and } \\
\text { Karacadağ } \\
(2004)\end{array}$ & $\begin{array}{l}\text { Mexican } \\
\text { peso vs. } \\
\text { US dollar }\end{array}$ & $\begin{array}{l}8.96-6.03, \\
\text { daily }\end{array}$ & $\begin{array}{l}\text { time series, } \\
\text { GARCH }\end{array}$ & $\begin{array}{l}\text {-Analysis of IV effects on level and } \\
\text { volatility of exchange rate } \\
\text { - Asymmetry: USD-sales stabilize the } \\
\text { peso and increase volatility (purchas- } \\
\text { es do not) }\end{array}$ & + & - \\
\hline $\begin{array}{l}\text { Domaç and } \\
\text { Mendoza } \\
(2004)\end{array}$ & $\begin{array}{l}\text { Mexican } \\
\text { peso vs. } \\
\text { US dollar }\end{array}$ & $\begin{array}{l}8.96-6.01 \\
\text { daily }\end{array}$ & $\begin{array}{l}\text { time series, } \\
\text { exponential } \\
\text { GARCH }\end{array}$ & $\begin{array}{l}\text { - Presence of the central bank appreci- } \\
\text { ates peso by } 0.12 \text { percent } \\
\text { - Sale of } 100 \text { mill. USD appreciates } \\
\text { peso by } 0.08 \text { percent } \\
\text { - Sales of USD reduce volatility (pur- } \\
\text { chases have no effect) }\end{array}$ & + & + \\
\hline $\begin{array}{l}\text { Mandeng } \\
\text { (2003) }\end{array}$ & $\begin{array}{l}\text { Colombian } \\
\text { peso vs. } \\
\text { US dollar }\end{array}$ & $\begin{array}{l}7.02-10.02 \\
\text { daily }\end{array}$ & $\begin{array}{l}\text { event study, } \\
20 \text { - days } \\
\text { period }\end{array}$ & $\begin{array}{l}\text {-Central b. uses foreign exchange op- } \\
\text { tions to limit exchange rate volatility } \\
\text { - Limited and short-lived effect }\end{array}$ & n.a. & $(-)$ \\
\hline $\begin{array}{l}\text { Kamil } \\
(2008)\end{array}$ & $\begin{array}{l}\text { Colombian } \\
\text { peso vs. } \\
\text { US dollar }\end{array}$ & $\begin{array}{l}9.04-4.07 \text {, } \\
\text { daily }\end{array}$ & $\begin{array}{l}\text { time series, } \\
\text { GARCH }\end{array}$ & $\begin{array}{l}\text { - Central b. uses secret, sterilized IVs } \\
\text { - Two periods: first, easing monetary } \\
\text { policy; second, tightening } \\
\text {-IV effect only during the first period }\end{array}$ & $(+)$ & n.a. \\
\hline $\begin{array}{l}\text { Rincón and } \\
\text { Toro (2011) }\end{array}$ & $\begin{array}{l}\text { Colombian } \\
\text { peso vs. } \\
\text { US dollar }\end{array}$ & $1.93-7.10$ & $\begin{array}{l}\text { time series, } \\
\text { GARCH }\end{array}$ & $\begin{array}{l}\text {-No desired effects over long period } \\
\text {-IV plus capital control in combination } \\
\text { 2008-10 impact level without increas- } \\
\text { ing volatility }\end{array}$ & $(+)$ & $(-)$ \\
\hline $\begin{array}{l}\text { Humala and } \\
\text { Rodriguez } \\
\text { (2010) }\end{array}$ & $\begin{array}{l}\text { Peruvian } \\
\text { soles vs. } \\
\text { US dollar }\end{array}$ & $\begin{array}{l}6.93-7.07 \\
\text { daily, week- } \\
\text { ly, monthly }\end{array}$ & $\begin{array}{l}\text { time series, } \\
\text { Markov } \\
\text { switching }\end{array}$ & $\begin{array}{l}\text {-IVs increase clearly after } 2003 \\
\text {-IVs are always negatively related to } \\
\text { contemporaneous and lagged ex- } \\
\text { change rate changes } \\
\text { - No analysis of IV impact }\end{array}$ & n.a. & n.a. \\
\hline $\begin{array}{l}\text { Mundaca } \\
\text { (2011) }\end{array}$ & $\begin{array}{l}\text { Peruvian } \\
\text { soles vs. } \\
\text { US dollar }\end{array}$ & $1.04-12.09$ & $\begin{array}{l}\text { time series, } \\
\text { EGARCH }\end{array}$ & $\begin{array}{l}\text {-IVs have some level effect but do not } \\
\text { seem to shape expectations } \\
\text { - Shocks impact volatility less during } \\
\text { IV times }\end{array}$ & $(+)$ & $(+)$ \\
\hline $\begin{array}{l}\text { Adler and } \\
\text { Tovar } \\
(2011)\end{array}$ & $\begin{array}{l}\text { Several } \\
\text { currencies } \\
\text { vs. US } \\
\text { dollar }\end{array}$ & $\begin{array}{l}1.04-12.10 \\
\text { weekly (dai- } \\
\text { ly) }\end{array}$ & $\begin{array}{l}\text { panel fixed } \\
\text { effects }\end{array}$ & $\begin{array}{l}\text {-IVs have some level effect, the } \\
\text { amount is important } \\
\text {-Effectiveness is lower with more capi- } \\
\text { tal account openness } \\
\text { - More effectiveness when misaligned }\end{array}$ & $(+)$ & n.a. \\
\hline
\end{tabular}




\begin{tabular}{|c|c|c|c|c|c|c|}
\hline ASIA & & & & & & \\
\hline $\begin{array}{l}\text { Pattanaik } \\
\text { and Sahoo } \\
(2003)\end{array}$ & $\begin{array}{l}\text { Indian } \\
\text { rupee vs. } \\
\text { US dollar }\end{array}$ & $\begin{array}{l}6.95-6.03 \\
\text { monthly } \\
\text { (volatility } \\
\text { daily) }\end{array}$ & $\begin{array}{l}\text { time series, } \\
\text { 2SLS }\end{array}$ & $\begin{array}{l}\text {-Exchange rate regime is "managed } \\
\text { floating with no fixed target" } \\
\text { •Central bank reacts on increasing } \\
\text { volatility but has a limited effect; no } \\
\text { systematic IV against misalignment }\end{array}$ & n.a. & $(+)$ \\
\hline $\begin{array}{l}\text { Behera et } \\
\text { al. (2008) }\end{array}$ & $\begin{array}{l}\text { Indian } \\
\text { rupee vs. } \\
\text { US dollar }\end{array}$ & $\begin{array}{l}4.95-12.06 \\
\text { (monthly) }\end{array}$ & $\begin{array}{l}\text { time-series, } \\
\text { GARCH }\end{array}$ & $\begin{array}{l}\text {-IVs reduce volatility but has no level } \\
\text { effect (possibly because no target) } \\
\text { - Foreign inflows increase volatility }\end{array}$ & $(-)$ & + \\
\hline $\begin{array}{l}\text { Goyal and } \\
\text { Arora } \\
(2010)\end{array}$ & $\begin{array}{l}\text { Indian } \\
\text { rupee vs. } \\
\text { US dollar }\end{array}$ & $\begin{array}{l}11.05-12.08 \\
\text { (daily and } \\
\text { monthly) }\end{array}$ & $\begin{array}{l}\text { time series, } \\
\text { GARCH }\end{array}$ & $\begin{array}{l}\text {-IV dummies indicate volatility reduc- } \\
\text { tion and some level effect } \\
\text { - News tend to reduce volatility } \\
\text { - Central bank communication impacts } \\
\text { markets but is underutilized }\end{array}$ & $(+)$ & + \\
\hline $\begin{array}{l}\text { Guimarães } \\
\text { and } \\
\text { Karacadağ } \\
(2004)\end{array}$ & $\begin{array}{l}\text { Turkish } \\
\text { lira vs. US } \\
\text { dollar }\end{array}$ & $\begin{array}{l}3.01-10.03 \\
\text { daily }\end{array}$ & $\begin{array}{l}\text { time series, } \\
\text { GARCH }\end{array}$ & $\begin{array}{l}\text { - No level effect of IVs, although the } \\
\text { market may have anticipated the pre- } \\
\text { announced IVs } \\
\text {-IV reduces volatility short-term; ef- } \\
\text { fect refers to sales of reserves only in } \\
\text { a period of high uncertainty }\end{array}$ & - & $(+)$ \\
\hline $\begin{array}{l}\text { Domaç and } \\
\text { Mendoza } \\
\text { (2004) }\end{array}$ & $\begin{array}{l}\text { Turkish } \\
\text { lira vs. US } \\
\text { dollar }\end{array}$ & $\begin{array}{l}2.01-5.02 \\
\text { daily }\end{array}$ & $\begin{array}{l}\text { time series, } \\
\text { exponential } \\
\text { GARCH }\end{array}$ & $\begin{array}{l}\text { - Presence of the central bank appreci- } \\
\text { ates lira by } 0.09 \text { percent } \\
\text { - Sale of } 100 \text { mill. USD appreciates lira } \\
\text { by } 0.2 \text { percent } \\
\text { - Sales of USD reduce volatility (pur- } \\
\text { chases have no effect) }\end{array}$ & + & + \\
\hline $\begin{array}{l}\text { Herrera and } \\
\text { Özbay } \\
(2005)\end{array}$ & $\begin{array}{l}\text { Turkish } \\
\text { lira vs. US } \\
\text { dollar }\end{array}$ & $\begin{array}{l}3.95-2.99 \\
2.01-12.03 \\
\text { daily }\end{array}$ & $\begin{array}{l}\text { time series, } \\
\text { GARCH, } \\
\text { intervention } \\
\text { function }\end{array}$ & $\begin{array}{l}\text { - Analyze an IV function } \\
\text { - First period of managed floating, se- } \\
\text { cond period of free floating } \\
\text {-IVs increase volatility during the free } \\
\text { floating }\end{array}$ & - & $(-)$ \\
\hline $\begin{array}{l}\text { Ardiç and } \\
\text { Selçuk } \\
(2006)\end{array}$ & $\begin{array}{l}\text { Turkish } \\
\text { lira vs. US } \\
\text { dollar }\end{array}$ & $\begin{array}{l}3.01-10.03 \\
\text { daily }\end{array}$ & $\begin{array}{l}\text { time series, } \\
\text { VAR, } \\
\text { GARCH }\end{array}$ & $\begin{array}{l}\text {-No level impact found } \\
\text {-IVs reduce volatility }\end{array}$ & - & + \\
\hline $\begin{array}{l}\text { Akinci et } \\
\text { al. (2006) }\end{array}$ & $\begin{array}{l}\text { Turkish } \\
\text { lira vs. US } \\
\text { dollar }\end{array}$ & $\begin{array}{l}9.01-10.03, \\
\text { daily }\end{array}$ & $\begin{array}{l}\text { event study, } \\
\text { time series } \\
\text { (parameter } \\
\text { varying) }\end{array}$ & $\begin{array}{l}\text {-IVs have a weak impact on volatility } \\
\text { reduction at best } \\
\text {-IVs can impact exchange rate level } \\
\text { but depending on circumstances } \\
\text { - large IVs are more effective }\end{array}$ & $(+)$ & $(+)$ \\
\hline
\end{tabular}


EASTERN EUROPE

\begin{tabular}{|c|c|c|c|c|c|c|}
\hline $\begin{array}{l}\text { Égert and } \\
\text { Komárek } \\
(2006)\end{array}$ & $\begin{array}{l}\text { Czech } \\
\text { koruna vs. } \\
\text { euro }\end{array}$ & $\begin{array}{l}6.97-12.02, \\
\text { daily }\end{array}$ & $\begin{array}{l}\text { event study, } \\
10 \text { to } 30 \\
\text { days filter, } \\
\text { sign test }\end{array}$ & $\begin{array}{l}\text { - Regime is inflation targeting } \\
\text {-IVs aim for stabilizing the exchange } \\
\text { rate against appreciation } \\
\text {-IVs (or interest changes) alone are not } \\
\text { significantly successful, but they are } \\
\text { if coordinated }\end{array}$ & $+/-$ & n.a. \\
\hline $\begin{array}{l}\text { Disyatat } \\
\text { and Galati } \\
\text { (2007) }\end{array}$ & $\begin{array}{l}\text { Czech } \\
\text { koruna vs. } \\
\text { euro }\end{array}$ & $\begin{array}{l}9.01-10.02 \text {, } \\
\text { daily }\end{array}$ & $\begin{array}{l}\text { time series, } \\
\text { 2SLS }\end{array}$ & $\begin{array}{l}- \text { Policy environment see above } \\
\text {-IVs impact exchange rate level and } \\
\text { reduce unexpected changes } \\
\text { - No effect on volatility }\end{array}$ & + & $+/-$ \\
\hline $\begin{array}{l}\text { Gersl and } \\
\text { Holub } \\
\text { (2006) }\end{array}$ & $\begin{array}{l}\text { Czech } \\
\text { koruna vs. } \\
\text { euro }\end{array}$ & $\begin{array}{l}1.01-12.02 \text {, } \\
\text { daily }\end{array}$ & $\begin{array}{l}\text { time series, } \\
\text { intervention } \\
\text { function, } \\
\text { GARCH }\end{array}$ & $\begin{array}{l}- \text { Years } 2001-02 \text { without policy change } \\
\text { and with lots of IVs } \\
\text { • No level effect found; volatility rather } \\
\text { increases after IV }\end{array}$ & - & - \\
\hline $\begin{array}{l}\text { Scalia } \\
(2008)\end{array}$ & $\begin{array}{l}\text { Czech } \\
\text { koruna vs. } \\
\text { euro }\end{array}$ & $\begin{array}{l}7.02-12.02 \text {, } \\
\text { daily and } \\
\text { hourly }\end{array}$ & time series & $\begin{array}{l}\text {-Policy environment see above } \\
\text {-Examines high frequency order flow } \\
\text { - Market knowledge (non-secrecy) } \\
\text { about IVs increases IV impact }\end{array}$ & + & n.a. \\
\hline $\begin{array}{l}\text { Chmelarov } \\
\text { a and } \\
\text { Schnabl } \\
(2006)\end{array}$ & $\begin{array}{l}\text { Croatian } \\
\text { kuna vs. } \\
\text { D-Mark/ } \\
\text { euro }\end{array}$ & $\begin{array}{l}1.96-3.05 \\
\text { daily }\end{array}$ & $\begin{array}{l}\text { time series, } \\
2 \text { SLS }\end{array}$ & $\begin{array}{l}\text { - Sub-periods, consideration of capital } \\
\text { controls }(03-05) \\
\text { - Exchange rate level and volatility } \\
\text { determines IVs } \\
\text { - Asymmetry: more heavy IVs to stem } \\
\text { kuna depreciation }\end{array}$ & n.a. & n.a. \\
\hline $\begin{array}{l}\text { Égert and } \\
\text { Lang } \\
(2006)\end{array}$ & $\begin{array}{l}\text { Croatian } \\
\text { kuna vs. } \\
\text { D-Mark/ } \\
\text { euro }\end{array}$ & $\begin{array}{l}1.96-8.04 \\
\text { daily }\end{array}$ & $\begin{array}{l}\text { event study, } \\
\text { GARCH }\end{array}$ & $\begin{array}{l}\text { - Clear effect of IVs on the level } \\
\text { - Unclear effect on (un)conditional } \\
\text { volatility } \\
\text {-IVs more successful in 2000-04 }\end{array}$ & $(+)$ & $+/-$ \\
\hline $\begin{array}{l}\text { Égert } \\
\text { (2007) }\end{array}$ & $\begin{array}{l}5 \text { Eastern } \\
\text { European } \\
\text { currencies } \\
\text { (plus Tur- } \\
\text { key) }\end{array}$ & $\begin{array}{l}1.96-1.06 \\
\text { daily }\end{array}$ & event study & $\begin{array}{l}\text {-Distinction of pure IVs vs. interest } \\
\text { rate changes and oral intervention } \\
\text {-IVs have some level impact in Croa- } \\
\text { tia, Czech Rep., Slowakia, not in } \\
\text { Hungary, Romania (and Turkey) } \\
\text { - Oral intervention has no impact } \\
\text { - Combined IVs are most successful }\end{array}$ & $(+)$ & n.a. \\
\hline $\begin{array}{l}\text { Melvin et } \\
\text { al. (2009) }\end{array}$ & $\begin{array}{l}\text { Russian } \\
\text { ruble vs. } \\
\text { US dollar }\end{array}$ & $\begin{array}{l}\text { March 2002, } \\
\text { minutely }\end{array}$ & time series & $\begin{array}{l}\text { - Central bank limit orders keep ex- } \\
\text { change rate within a band; does not } \\
\text { change a fundamental trend } \\
\text {-IV increases volatility immediately } \\
\text { (information) but decreases thereafter } \\
\text { (calming) } \\
\text {-IV increases liquidity }\end{array}$ & $(+)$ & $+/-$ \\
\hline
\end{tabular}

Note: ${ }^{1}$ Lev. and Vol. represent the impact of intervention on exchange rate level and exchange rate volatility, respectively. 